\title{
National Children's Bureau series
}

Editor: Ronald Davie

This series examines contemporary issues relating to the development of children and their needs in the family, school and society. Based on recent research and taking account of current practice, it also discusses policy implications for the education, health and social services. The series is relevant not only for professional workers, administrators, researchers and students but also for parents and those involved in self-help movements and consumer groups.

Combined Nursery Centres

Elsa Ferri, Dorothy Birchall,

Virginia Gingell and Caroline Gipps

Growing Up in Great Britain

Ken Fogelman (editor)

Children in Changing Families: a Study of Adoption and Illegitimacy

Lydia Lambert and Jane Streather

Caring for Separated Children

R. A. Parker (editor)

A Fairer Future for Children

Mia Kellmer Pringle

The Needs of Parents: Practice and Policy in Parent Education Gillian Pugh and Erica De'Ath

Unqualified and Underemployed: Handicapped Young People and the Labour Market

Alan Walker 


\section{Also by Gillian Pugh}

Shared Care: support services for families with handicapped children Preparation for Parenthood (editor)

Parents as Partners: intervention schemes and group work with parents of handicapped children

Perspectives on Preschool Home Visiting (editor) 


\section{The Needs of Parents}

\section{Practice and Policy in Parent Education}

Gillian Pugh and Erica De'Ath

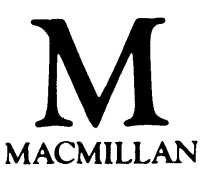


(C) National Children's Bureau 1984

Softcover reprint of the hardcover 1st edition 1984

All rights reserved. No part of this publication may be reproduced or transmitted, in any form or by any means, without permission

First published 1984 by

Higher and Further Education Division

MACMILLAN EDUCATION LTD

Houndmills, Basingstoke,

Hampshire, RG21 2XS,

and London

Companies and representatives

throughout the world

Filmsetting by Vantage Photosetting Co. Ltd

Eastleigh and London

British Library Cataloguing in Publication Data

Pugh, Gillian

The needs of parents

1. Child welfare-Great Britain

I. Title II. De'Ath, Erica

362.7'0941 HV751

ISBN 978-0-333-37327-9 ISBN 978-1-349-17559-8 (eBook)

DOI 10.1007/978-1-349-17559-8 


\section{Contents}

List of Tables and Figures $\quad$ ix

List of Abbreviations $\quad \mathrm{x}$

Acknowledgements xiii

Introduction 1

National Children's Bureau and parent education 2

The Bureau's parenting project 3

How the book is organised 6

\section{Part I WHY PARENT EDUCATION?}

1 Parenting in the 1980s 11

Introduction 11

The tasks and skills of parenting 15

Factors affecting the way parents bring up their children $\quad 19$

Changing family patterns $\quad 23$

marriage 24

divorce $\quad 24$

one-parent families 25

remarriage and step-families $\quad 26$

adoption $\quad 28$

Family size $\quad 28$

Where are the children? $\quad 29$

Changes in society as they affect family life $\quad 30$ the changing role of women 31

patterns of work and unemployment $\quad 32$

the family and the welfare state $\quad 34$ 


\section{vi Contents}

2 Parent Education $\quad 37$

Historical perspectives $\quad 37$

The case for parent education $\quad 42$

A life-cycle approach to parent education $\quad 46$

Methods of parent education 53

mass media $\quad 53$

group work $\quad 56$

individual approaches $\quad 57$

Personnel in parent education $\quad 58$

Training $\quad 60$

Evaluation $\quad 62$

\section{Part II PARENT EDUCATION IN PRACTICE}

3 Family Life Education: The Role of the School 65

Introduction 65

Aims and approaches $\quad 69$

A national perspective $\quad 72$

primary schools $\quad 73$

secondary schools $\quad 75$

People and resources $\quad 85$

Training and support for teachers $\quad 88$

$\begin{array}{ll}\text { Summary } & 90\end{array}$

4 Young People out of School 92

Introduction $\quad 92$

The youth service and social education $\quad 93$

Informal youth service provision $\quad 94$

Preparation for working and adult life:

the Youth Training Scheme 99

Formal educational settings $\quad 101$

Other education opportunities 103

intermediate treatment (IT) 103

prison 104

Teenage parents $\quad 105$

schoolgirl mothers 106

single mothers (16-19 years old) 108

teenage marriages and parenthood 111

$\begin{array}{ll}\text { Summary } & 112\end{array}$ 
5 Antenatal Education and the Transition to Parenthood 115

Introduction

Planning parenthood

Pre-conceptual care

Becoming a parent

118

Antenatal care

antenatal clinics

antenatal classes

124

Choices and options in childbirth

Post-natal care and support

Special areas and needs

Summary

6 Parents with Pre-school Children

Introduction

Widely available services

individual approaches

informal post-natal and parent and toddler groups

groups and schemes with a particular emphasis on parenting: playgroups, parent education groups advice and information

Working with vulnerable families

adult and community education

closer liaison between home and school

toy libraries

family groups

family centres

home-based programmes

crisis phone services

intensive work with families

Summary

\section{Parents of School-age Children}

Introduction

Parents and schools

background influences

recent developments

parental involvement in schooling

Parents and pre-adolescents 
viii Contents

Parents and adolescents $\quad 184$

the generation gap and family relationships $\quad 186$

services for parents and adolescents $\quad 186$

Summary

\section{Part III A POLICY FOR PARENT EDUCATION}

8 Parent Education and Support: Summary of Main Issues and Recommendations

Summary of main issues

Some common themes

Recommendations for policy-makers and practitioners

Appendices

1 Organisations and individuals consulted

2 Examinations in child-care and development

3 Resources for parent education

4 Basic training package 


\section{List of Tables and Figures}

Table 1.1 Children by age and where currently living, Great Britain, 1979

2.1 Methods of parent education $\quad 54$

2.2 Methods in relation to objectives 59

4.1 Courses provided in colleges of further education relating to parent education

4.2 Legal abortions and live births to girls under 16 resident in England and Wales

6.1 Parent education activities available at one or more adult education institutions, ILEA

7.1 Percentage of mothers aged 16-59 who go out to work (1980)

Figure 1.1 Different types of lone-parent families in Great Britain, 1979

3.1 Host subject groups for preparation for parenthood in the optional and compulsory curriculum for five LEAs 


\section{List of Abbreviations}

ACE

AIMS

APNI

ATW

BAECE

BBC

BFUW

BMA

BON

CACE

CAP

CASE

CEDC

CERI

CETHV

CDT

CHAT

COFACE

CHSC

CSE

CSV

CTVC

CWLA

EOC

EPA

FLEEP

FPA

FSU

FWA
Advisory Centre for Education

Association for Improvement in the Maternity

$$
\text { Services }
$$

Association for Post-natal Illness

Active tutorial work

British Association for Early Childhood Education

British Broadcasting Corporation

British Federation of University Women

British Medical Association

British Organisation for Non-parents

Central Advisory Council for Education

Calderdale Association for Parents

Confederation for Advancement of State Education

Community Education Development Centre (Coventry)

Centre for Educational Research and Innovation

Council for the Education and Training of Health Visitors

Community Development Trust

Contact Health and Teaching

Confederation of Family Organisations in the European Community

Central Health Services Council

Certificate of Secondary Education

Community Service Volunteers

Churches Television Council

Child Welfare League of America

Equal Opportunities Commission

Educational Priority Area

Family Life Education Ecumenical Project

Family Planning Association

Family Service Units

Family Welfare Association 


$\begin{array}{ll}\text { GAFL } & \text { Gloucester Association for Family Life } \\ \text { GCE } & \text { General Certificate of Education } \\ \text { GP } & \text { General Practitioner } \\ \text { HEC } & \text { Health Education Council } \\ \text { HMI } & \text { Her Majesty's Inspectorate } \\ \text { HMSO } & \text { Her Majesty's Stationery Office } \\ \text { HVA } & \text { Health Visitors Association } \\ \text { IBA } & \text { Independent Broadcasting Authority } \\ \text { IFPE } & \text { International Federation for Parent Education } \\ \text { ILEA } & \text { Inner London Education Authority } \\ \text { INSTEP } & \text { In-service Training and Education Panel } \\ \text { IUFO } & \text { International Union of Family Organisations } \\ \text { LEAs } & \text { Local Education Authorities } \\ \text { MAMA } & \text { Meet a Mum Association } \\ \text { MSAC } & \text { Maternity Services Advisory Committee } \\ \text { MSC } & \text { Manpower Services Commission } \\ \text { NAMCW } & \text { National Association for Maternal and Child } \\ & \text { Welfare } \\ \text { NAWCH } & \text { National Association for the Welfare of Children in } \\ & \text { Hospital } \\ \text { NAYPCAS } & \text { National Association of Young People's Counselling } \\ & \text { and Advisory Services } \\ \text { NCB } & \text { National Children's Bureau } \\ \text { NCDS } & \text { National Child Development Study } \\ \text { NCH } & \text { National Children's Home } \\ \text { NCOPF } & \text { National Council for One Parent Families } \\ \text { NCPTA } & \text { National Council of Parent Teacher Associations } \\ \text { NCT } & \text { National Childbirth Trust } \\ \text { NCMA } & \text { National Childminding Association } \\ \text { NCVO } & \text { National Council for Voluntary Organisations } \\ \text { NCVYS } & \text { National Council for Voluntary Youth Service } \\ \text { Newpin } & \text { New Parent-Infant Network } \\ \text { NFCA } & \text { National Foster Care Association } \\ \text { NHS } & \text { National Health Service } \\ \text { NMGC } & \text { National Marriage Guidance Council } \\ \text { NNEB } & \text { National Nursery Education Board } \\ \text { NSPCC } & \text { National Society for the Prevention of Cruelty to Children } \\ \text { NUS } & \text { National Union of Students } \\ \text { NUT } & \text { National Union of Teachers } \\ \text { OECD } & \text { Organisation for Economic Co-operation and } \\ & \text { Development } \\ \text { OPCS } & \text { Office of Population Censuses and Surveys } \\ \text { OPUS } & \text { Organisation for Parents under Stress } \\ \text { OU } & \text { Open University } \\ \text { PACT } & \text { Parents Children and Teachers } \\ \text { PET } & \text { Parent Effectiveness Training } \\ \text { PMS centres } & \text { psycho-pedagogical-medical-social centres } \\ \text { PPA } & \text { Pre-School Playgroups Association } \\ & \end{array}$




\begin{tabular}{|c|c|}
\hline PTA & Parent Teacher Association \\
\hline RCGP & Royal College of General Practitioners \\
\hline RCM & Royal College of Midwives \\
\hline RCOG & Royal College of Obstetricians and Gynaecologists \\
\hline SCHEP & Schools Council Health Education Project \\
\hline SLS & social and life skills \\
\hline TACADE & $\begin{array}{l}\text { Teachers Advisory Council on Alcohol and Drug } \\
\text { Abuse }\end{array}$ \\
\hline $\mathrm{VCHC}$ & Voluntary Council for Handicapped Children \\
\hline YFDCA & Young Family Day Care Association \\
\hline YOP & Youth Opportunity Programme \\
\hline YSDC & Youth Service Development Council \\
\hline YTS & Youth Training Scheme \\
\hline
\end{tabular}

\section{Reports}

Usually known as

Albemarle report

Court report

Crowther report

Hunt report

Latey report

Macnaughton report

Miles report

Milson-Fairbairn report

Newsom report

Peel report

Plowden report

Short report

Skeet report

Taylor report

Thompson report

Warnock report
See reference under

Ministry of Health (1960)

Committee on Child Health Service (1976)

Central Advisory Council for Education (1959)

Youth Services Development Council (1967)

Lord Chancellor's Office (1967)

Royal College of Gynaecologists (1982)

National Council for One Parent Families (1979)

YSDC (1969)

CACE (1963)

Central Health Services Council (1970)

CACE (1967)

House of Commons, Social Services Committee

House of Commons, Youth and Community Bill

DES and Welsh Office (1977)

DES (1982)

Committee of Enquiry into the Education of the Handicapped 


\section{Acknowledgements}

Many people have contributed to the development of this book, by discussing their thoughts on parent education with us or by attending one of the seventy or so conferences set up during the course of the Bureau's parenting project. Some of the main groups and organisations we have consulted are listed in Appendix 1, and we are grateful to them for their time and their ideas. Particular thanks go to those who served on the working party which produced $A J o b$ For Life, a document which has guided our thinking throughout the project: Kate Torkington and Joan Kidd with whom the booklet was written and Brenda Crowe, Ken David, Gill Feeley, Heather Hyde, Jill Manning Press, Lin Poulton and government observers Rachel Lockwood, HMI (DES), and Dr Barbara Ely, Hilda Kell and Daphne Learmont (DHSS).

Colleagues to whom we are grateful for their constructive comments on all or part of earlier drafts of this book include Ron Davie, Dorothy Birchall, Elsa Ferri, Dorothy Henderson, Richard Ives, Lydia Lambert and Christine Such (from the Bureau); and, from outside the Bureau, Dorit Braun, John Coleman, Bernard Davies, Shirley Goodwin, Margaret Harrison, Janet Paraskeva Hunt, Lesley Rimmer, Sheila Shinman, Lesley Smith, Willem van der Eyken and, in particular, Kate Torkington. Many helpful comments were made, but the responsibility for the final manuscript is entirely ours. Our thanks, too, to Ian Vallender and Biddy Cunnell for laboriously checking through our numerous references.

Neither the book nor the project would have been possible without the hard work and commitment of our secretary, Margery Geoghegan, and we wish her a happy and well-deserved retirement.

And finally our grateful thanks go to the late Mia Pringle, who 
xiv Acknowledgements

sought and obtained funding for the project on which the book draws, and to the Department of Health and Social Security who responded to her request for funding.

GILLIAN PUGH

ERICA DE'ATH 